\title{
Inhibition of Juice Komba-Komba Chromolaena odorata Leaf Against Growth of Bacteria Staphylococcus Aureus
}

\author{
Reni Yunus, Muh.Hilman \& Satya Darmayani \\ Department of Health Analyst, Poltekkes Kemenkes Kendari
}

\begin{abstract}
Nowadays many plants can be used as traditional medicines to overcome various diseases including infections, because the use of traditional medicines is relatively safer compared to drugs derived from chemicals. One of the local plants in Southeast Sulawesi that has been empirically used as a medicine for wounds is a race of plants. Komba-komba leaves Chromolaena odorata containcompounds alkaloid, flavonoids, tannins, phenols, triterpenoids, saponins and steroids which have their respective functions in inhibiting the growth of microorganisms or antibacterial. This study aims to determine the inhibition of komba-komba leaf extract Chromolaena odorata on the growth ofbacteria Staphylococcus aureus. This type of research is experimental laboratories. The method used was agar diffusion with 5 treatment concentrations, namely komba-sheep leaf extract concentration Chromolaena odorata $20 \%, 40 \%, 60 \%, 80 \%$ and $100 \%$, positive control (tetracycline) and negative control (aquadest) and repetition. The results showed that there was a inhibition zone of komba-komba leaf extract Chromolaena odorata on the growth ofbacteria Staphylococcus aureus at a concentration of $20 \%$ at $2 \mathrm{~mm}$, a concentration of $40 \%$ at $3.7 \mathrm{~mm}$, a concentration of $60 \%$ at $4.7 \mathrm{~mm}$, a concentration of $80 \% 6.2 \mathrm{~mm}$ and a concentration of $100 \%$ by $8 \mathrm{~mm}$.
\end{abstract}

\section{Article History}

Received 13 February 2019

Accepted 24 June 2019

Keyword

Chromolaena odorata, Staphylococcus aureus, antibacterial activity

\section{Introduction}

Indonesia is a tropical country that has high biodiversity, making Indonesia has many plants used by the community as traditional medicine. In Indonesia there are around 30,000 types of plants and 7,000 of them have medicinal properties. Indonesia's diversity of biological resources ranks second after Brazil (Jumiarni \& Komalasari, 2017).

All types of plants have long been targeted as new drug searches. The development of drug use, especially from plants to help improve public health. One of the benefits of using drugs from these plants is the Kirinyuh (plantChromolaena odorata) which is used as an antibacterial (Awoyinka, 2007). Empirical studies on the local community of the Muna tribe show the use of this leaves as a wound healer. Kirinyuh leaves Chromolaena odorata in the local community of the Muna tribe are known as the leaves of "Komba-komba" (Jumiarni \& Komalasari, 2017). 
Indonesia is a tropical country so the prevalence of infectious diseases caused by bacteria is still high. One of the bacteria that infects wounds on the skin is thebacteria Staphylococcus aureus. bacteria Staphylococcus aureus infects wounds, zits, ulcers and others. These wounds are usually treated with antibiotics which can inhibit inflammation and kill bacteria, for example tetracycline, erythromycin, cloromhenicol, doxycycline and clindamycin. However, these drugs have side effects, namely irritating the skin to the wound or to zits, while the use of long-term antibiotics can also cause resistance and can cause organ damage and immuno hypersensitivity (Djajadisastra, 2009).

The prevalence of skin infections is increasing. Based on the results of the Nindya Nugerahdita 2009 study on the prevalence of skin disease and treatment in the Petamburan area of central Jakarta, the results showed that the prevalence of skin diseases of $(47.57 \%)$ of 103 families observed in the Petamburan village in central Jakarta with the most skin diseases was caused by ( $71.43 \%)$ and the remainder is caused by bacteria of $(28.57 \%)$.

In this era, many plants can be used as traditional medicines to treat various diseases including infections, because many people assume that the use of traditional medicines is relatively safer compared to drugs derived from chemicals. One of the plants that can be used as medicine is the komba-komba or kirinyuh plants. Leaves of komba-komba or kirinyuh Chromolaena odorata contain compounds alkaloid, flavonoids, tannins, phenols, triterpenoids, saponins and steroids which have their respective functions in inhibiting the growth of microorganisms or antibacterials (Dalimartha, 2000).

Previous research has shown that komba-komba leaves extract ointment or at a concentration of $20 \%$ has an effect in accelerating wound healing in laying hens (Rahman, 2017). In this study we used komba komba leaf extract without the addition of other chemical solvents such as ethanol or methanol to obtain active compounds. The reason researchers chose juice of komba komba leaf, without addition the chemical solvents, is that in its application as a natural antibiotic, people can make it easier.

Based on the antibiotic content found in komba-komba leaf (Choromolaena odorata) which has efficacy as an antibacterial, researchers are interested in conducting research on "inhibition test of juice komba-komba leaf (Choromolaena odorata) on the growth of bacteria Staphylococcus aureus".

The purpose of this study was to determine the inhibition of juice komba-komba leaf Chromolaena odorata to the growth of Staphylococcus aureus and to determine the inhibition of juice komba-komba leaf Chromolaena odorata on the growth ofbacteria Staphylococcus aureus at concentrations of $20 \%, 40 \%, 60 \%, 80 \%$ and $100 \%$.

\section{Materials and Methods}

This study was conducted in March-June 2018 at the Microbiology Laboratory of the Department of Health Analyst at the Poltekkes Kendari. The method used is experimental laboratories, using the One-shot Case Study design, namely research design with treatment ofvariables independent.

The inhibitory test of juice komba-komba Chromolaena odorata leaf using method agar diffusion. Data obtained by measuring the diameter of the inhibitory zone formed. Measurements were made twice with positive control tetracycline of $19 \mathrm{~mm}$. 


\section{Tools and Materials}

The tools used are digital balance, horn spoon, erlenmeyer, stirring rod, measuring pipette, ball filler, measuring cup, lamp spirits, three feet, wire mesh, incubator, atoclave, porcelain cup, test tube, tube rack, wire ose, tweezers, spray bottle, blender, filter paper, dropper pipette, ruler / ruler, funnel, beaker. The ingredients used were leaves of sheep Chromolaena odorata, antibiotics tetracycline, disc paper blank, media nutrient agar (NA), aquadest, filter paper, label paper, aluminum foil, pure culture of Staphylococcus aureus.

\section{Pure Stock Making of Staphylococcus aureus}

Bacteria The test bacteria used or bacteria to be purified is Staphylococcus aureus. The making of bacterial stock is carried out using ose then planted or inoculated by scraping on themedia NA slopingand then incubated in an incubator temperature of $37^{\circ} \mathrm{c}$ for $1 \times 24$ hours. Making Test Bacterial Suspensions.

The making of bacterial suspension was taken by test bacteria by using sterile ose wire and then suspended in $2 \mathrm{mLNaCl} 0.9 \%$ in a sterile test tube and homogenized according to the standard Mc. Farland 0.5 which is characterized by the formation of turbidity after being suspended.

\section{Sampling and Preparation of Samples}

Leaves of komba - komba Chromolaena odorata taken are cleaned in washing with running water then stored at room temperature until dry after that the leaves are weighed as much as $\mathbf{5 0 0}$ grams then in a blender.

\section{Making juice of Komba-Komba leaves Chromolaena odorata}

Weighed 500 grams of leaves of the sheep Chromolaena odorata using digital scales and then blended and squeezed and filtered as much as $150 \mathrm{~mL}$ ago made in 5 variations of concentration, namely in variations in concentrations of $20 \%, 40 \%, 60 \%, 80 \%$, and $100 \%$.

\section{Preparation of Tetracycline Antibiotic (Positive Control) \\ Tetracycline $250 \mathrm{mg}$ created a concentration of $5 \%$ by weighing 0.5 grams of tetracycline then dissolved}

\section{Tests Antibacterial Activity}

Antibacterial activity tested by usingmethod agar diffusion (Disk Diffusion Method)of the Kirby-Bauer. Themethod is diffusion carried out by means of a 0.1 bacterial suspension $\mathrm{mL}$ spread on the surface ofmedia Nutrient Agar (NA)by using ski gel then the paper disc is dipped in the leaf extract of the sheep Chromolaena odorata at each concentration of $20 \%, 40 \%, 60$, $80 \%$ and $100 \%$ using tweezers stored on the surface ofmedia Nutrient Agar (NA)then labeled using label paper. Then a positive control was made using tetracycline paper disc dipped in tetracycline for positive control and planted on the surface of the media Nutrient Agar (NA) and then incubated for $1 \times 24$ hours temperature $37^{\circ} \mathrm{c}$.

\section{Results and Discussion}

This study shows that the juice of the leaf Komba-komba Chromolaena odorata has a inhibitory effect on Staphylococcus aureus. Testing of inhibition was carried out twice repetition, the first major inhibition was found at a concentration of $100 \%$ with a diameter of $10.5 \mathrm{~mm}$ and the smallest inhibition was found at a concentration of $20 \%$ with a diameter of 
$1.5 \mathrm{~mm}$ while in the repetition of both power the biggest inhibition was at a concentration of $100 \%$ with a diameter of $5.5 \mathrm{~mm}$ and the smallest inhibition was found at a concentration of $20 \%$ with a diameter of $2.5 \mathrm{~mm}$. For the results of research the inhibitory zone can be seen more clearly in figure 1 and table 1 below.

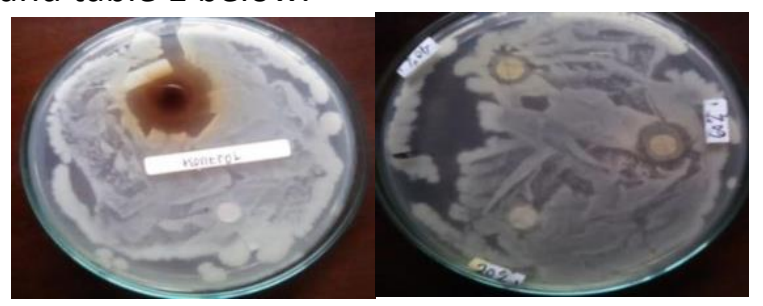

Figure 1. inhibition zone formed after incubation

Table 1. Results Measurement of inhibition zones juice of komba-komba leaf Chromolaena odorata on the growth of bacteria Staphylococcus aureus

\begin{tabular}{|c|c|c|c|c|}
\hline No & Concentration & $\begin{array}{l}\text { Observaton } \\
\text { time }\end{array}$ & $\begin{array}{l}\text { Average diameter of } \\
\text { inhibition zone }\end{array}$ & Interpretation \\
\hline 1 & $20 \%$ & 24 hours & $2 \mathrm{~mm}$ & Resistent \\
\hline 2 & $40 \%$ & 24 hours & $3,7 \mathrm{~mm}$ & Resistent \\
\hline 3 & $60 \%$ & 24 hours & $4,7 \mathrm{~mm}$ & Resistent \\
\hline 4 & $80 \%$ & 24 hours & $6,2 \mathrm{~mm}$ & Resistent \\
\hline 5 & $100 \%$ & 24 hours & $8 \mathrm{~mm}$ & Resistent \\
\hline 6 & Control (+) & 24 hours & $19 \mathrm{~mm}$ & Sensitive \\
\hline 7 & Control (-) & 24 hours & - & - \\
\hline
\end{tabular}

\section{Discussion}

In the test of inhibitory power of juice of komba-komba Chromolaena odorata leaf which will be tested on bacteria Staphylococcus aureus with using method agar diffusion or scatter method with juice of komba-komba leaf testing Chromolaena odorata made in 5 variations of concentration, namely concentrations of $20 \%, 40 \%, 60 \%, 80 \%$ and $100 \%$ carried out in the Laboratory of Health Polytechnic Kendari Department of Health Analyst.

The testing of inhibition power of juice komba-komba leaf Chromolaena odorata on the growth of bacteria was Staphylococcus aureus carried out in several stages, starting from the leaf selection stage to testing the bacterial inhibition. The stage of leaf selection is done by selecting leaves that are still young and taken by manual then carried out until the stage of making the concentration for testing the inhibitory power.

Testing the inhibition of the growth of Staphylococcus aureus by using themethod diffusion to be incubated for $1 \times 24$ hours in an incubator with inhibition zones was characterized by the formation of clear areas around the paper disc, using drugs tetracycline as a positive control and aquadest as a negative control.

The inhibitory power of juice komba-komba Chromolaena odorata leaf at a concentration of $20 \%$ inhibition zone formed an average of $2 \mathrm{~mm}$. The concentration of $40 \%$ of the inhibition zone formed $3.7 \mathrm{~mm}$. The concentration of $60 \%$ of the inhibition zone formed $4.7 \mathrm{~mm}$. Concentration of $80 \%$ inhibition zone $6.2 \mathrm{~mm}$. The concentration of $100 \%$ of the inhibition zone formed is $8 \mathrm{~mm}$. So that from the 5 concentrations formed a clear area around the paper disc which is called the inhibitory zone. The inhibitory zone formed is still categorized as resistant (weak) because of the large inhibition zone formed less than $12 \mathrm{~mm}$ but at a concentration of $100 \%$ in this test although it is included in the category of resistance 
but effective in inhibiting the growth of Staphylococcus aureus because it has the greatest inhibitory power testing this obstacle.

This is in line with the research of Purwati and Undri Rastuti (2009) explaining ethyl acetate leaf Euphatorium odoratum extracts based on screening of secondary metabolites containing flavonoids, with secondary metabolites in extract of ethyl acetate leaves Euphatorium odoratum has antioxidant activity with a sequence of inhibitory activities of 0.15 $\%$ (b / v). Flavonoids denaturate bacterial cell proteins and can damage bacterial cytoplasmic membranes so that they can inhibit the growth of bacteria Staphylococcus aureus in testing the inhibitory power.

In another study (Rahman, 2017) also used Chromolaena odorata leaf extract incisive forwound healing in laying hens, which in their study showed that the effective concentration of deep wound healing in laying hens was at a concentration of $20 \%$.

The previous research by Vital and Rivera (2009) in his research carried out a test of the antimicrobial activity ofleaf extract Chromolaena odorata, the results showed positive forbacteria Bacillus subtillis, Staphyloccus aureus and Salmonella typhimurium. Previous research also showed the effectiveness ofextract of ethanol leaves of Chromolaena odorata in wound healing in male mice (Afrianti, 2010).

\section{Conclusions}

The research show that juice of leaf komba-komba Chromolaena odorata has inhibition power to the growth of bacteria Staphylococcus aureus.

\section{References}

Afrianti, R, R. Yenti, and L. Afriani, 2010., Preliminary studies of leaves of ethanol are important for wound healing, STIFL Research Report, Padang.

Ayesha. 2015. Inhibitory Power of Pandan Wangi Extract (Pandanus amaryllifolius Roxb.) Against Staphylococcus aureus Bacterial Growth. Faculty Makassar UNHAS Dentistry. Thing.

Ajizah, Aulia; Thihana; Mirhanuddin. 2007. Potential of ironwood extract (Eusideroxylonzwageri) in inhibiting In Vitro Staphylococcus aureus bacterial growth.On line. Available at:.http://bioscientiae.unlam.ac.id/v4n1/v4n1_ajizah.pdfEncryption (Accessed, 5 January 2018).

Apriani. 2012. Review of the Plant Library Komba - Komba Chromolaena odorata. Accessed pdf on August 2, 2017.

Apriyadi Tri Erza. 2010. The Risk of Staphylococcus aureus in Traditional Food Ready to Eat and Evaluate Its Presence in Uduk Rice. Faculty of Agricultural Technology Bogor Agricultural University p. 6.

Aulia, Ismi Arsyi. 2008. Antibacterial activity test Ethyl acetate fraction Ethanolic extract of Arbenan leaves (duchesnea indica (andr.) Focke) against Staphylococcus aureus and Pseudomonas aeruginosa Multiresisten Antibiotics along with Thin Layer Chromatography Profiles. On line. Available at:http://etd.eprints.ums.ac.id/1517/1/K100040115.pdf. Thesis (Accessed, 5 January 2018)

Awoyinka. 2007. Traditional Plants as Antibacterials for Treatment. Penebar Swadaya: Jakarta. 
Bachtiar Subhchan Yusuf, Tjahjaningsih, Nanik Sianita. 2012. Effect of Brown Algae Extract Sargasus sp on Escherichia coli bacterial growth. Faculty of Fisheries and Marine Airlangga University. Journal of Marine and Coastal Science, 1 (1) pp. 53-60.

Brooks GF, Butel JS, Morse SA. Medical microbiology book 1. Interpreting: Mudihardi E, et al, editor. Jakarta: Salemba medika; 2005, p. 317-22

Brooks GF, Carroll C, Butel JS, Morse SA, Mietzner A. Melnick \& adelberg's medical microbiology 25years. USA: Mc Graw Hill; 2010, pp. 617

Cappuccino, JG \& Natalie, S. 2013. Biology Laboratory Manual; language transfer, Nur Miftahurrahmah. Jakarta: EGC.

Dalimartha, S., 2000. Atlas of Plants Indonesian Medicine Edition 2. Jakarta: Trubus Agiwidya. Djajadisastra, Joshita, et al., 2009.Tropic Gel Formulation from Nerii Folium Extract in AntiAcne Preparations. Indonesian Pharmacy Journal Vol.4 No.4 July 2009: 210-216. Universitas Indonesia Faculty of Mathematics and Natural Sciences.

Dwidjoseputro D. 1994. Basics of Microbiology. Djambat, Jakarta.

Hadi, M., JW Hidayat, K. Baskoro. 2000. Test the Potential of Eupatorium odoratum Leaf Extract as an Alternative Insecticide Material: Toxicity and Effects on the Larvae of Heliothis armigera. Hubner. Journal of Science and Mathematics. Undip Faculty of MIPA. Semarang

Harbone, JB, 1987., Phytochemical Method Determination of Modern Analysis of Plants, Translated by Kosasih, Padmawinata, Issue of ITB, Bandung.

Jawetz, et al., 2010. Medical Microbiology. translated Mudihardi, E., Kuntaman, Wasito, EB, Mertaniasih, NM, Harsono., S., Alim sardjono, L., Edition XXV, 198, Publisher Salemba Medika, Jakarta.

Jumiarni Wa Ode, Oom Komalasari. 2017. "Exploitation of Types and Utilization of Medicinal Plants in Muna Society in Muna City Settlement" Traditional Medicine Journal, 22 (1) 2017 p. 45

Kurniawan, B., Aryana, WF, 2015. Binahong (Cassia alata L) as inhibitor of Escherichia coli Growth. Majority, 4(4), 100-104.

Kusuma, IW, Kuspradini, H., Arung, ET, Aryani, F., Min, YH, Kim, JS, Kim, YU, 2011. Biological Activity and Phytochemical Analysis of the Three Indonesian Medicinal Plants, Murraya koenigii, Syzygium polyanthum andZingiber purpurea. Journal of Acupuncture and Meridian Studies, 4(1), 7579.

Loggia, RD, Tubaro A., Dri P., Zilli C., and Del Negro P. 1986. The role of flavonoids in the antiinflammatory activity of Chamoliarecutita. Plant flavonoids in biology and medicine: biochemical, pharmaceutical and structure-activity relationships. Alan R. Liss, Inc. p. 481-4.

Madigan, MT, JM, et al. 2009. Brock Biology of Microorganisms, Pearsons enjamin Cummings, San Francisco, pp. 779

Nugerahita Nindya. 2009. Prevalence of Skin Disease and its Treatment in Several RWs in Petamburan Village, Central Jakarta. University of Indonesia Faculty of Mathematics and Natural Sciences Depok 2009. Department of Pharmacy,

Pratiwi ST. Pharmaceutical microbiology. Jakarta: Erlangga; 2008, p. 42-3, 188-91

Purwati and Undri R. 2009. Screening of Secondary Metabolite Compounds and Antioxidant Activity Test of Ethylacetate Wedusan Leaf Extract (Euphatorium odoratum) Molecules, chemistry study program, MIPA department, Faculty of Science and Engineering UNSOED vol. 4.No. 2. November, 2009: 94-104. 
Purwiyanto Anna ISMSi. 2013. Practical Chemistry Oceanography Module. Faculty of Mathematics and Natural Sciences Sriwijaya University.

Rahman Aminul. 2017. Effects of Ointment of Kirinyuh Leaf Extract (Euphatorium odaratum) on the Healing of Vegetable Wounds in Laying Hens (Gallus leghorn). Veterinary Medicine Study Program, Faculty of Medicine, Hasanuddin University, Makassar 2017.

Robinson, T, 1995., High Plant Organic Content, Edition VI, ITB, Bandung.

Sagala, NS 2009. Utilization of White Bunag Shrubs (Chromolena odarata) Against Growth and IOFC In Ramsun Quail (Cortunix-cortunix japonica) Age 1 to 42 Days. USU, Medan.

Samaranayake. 2012. Essential Microbiology For Dentistry 4th ed. China: Elsevier; 2012, pp. 125

Simanjuntak, MR 2008. Extraction and Fractionation of the Components of Senduduk Plant Leaf Extract (melastoma malabathricum. L) and Testing the Effect of Cream Preparations on Burning Healing. Thesis. University of North Sumatra. Field. 85 p.

Sugiyono. 2011. Quantitative and Qualitative Research Methods (Print No. 14). Bandung: Alfabeta

Tedy Nurwalidin Aka. 2005. Effectiveness of Antibacterial Ethanol Extract and Ethyl Acetate Ketapang Leaf (Terminalia catappa I.) Against Salmonella Typhy and Staphylococcus epidermidis. Thesis of the Science and Technology Faculty and Sunan Kalijaga Technology.

Thamrin, M., S. Asiklin and M. Willis. 2013."Plant Kirinyuh Chromolaena odorata As a Vegetable Insecticide for Controlling Grayworms (Spodoptera litura)". Journal of vegetable insecticides, 22 (7) 2013 p. 113

Toy Torar SS, Benedictus S. Lampus, Bernat SP Hutagalung. 2015. The Inhibition Test of Gracilaria sp Seaweed Extract Against Staphylococcus aureus Bacterial Growth. E-GiGi Journal (eG). Volume 3 Number 1 January - June 2015. Page 156.

Vital, PG, and W. L, Rivera, 2009.Antimicrobacterial activity and citoxicity of chromolaena odorata (LF) King and Robinson and Uncaria perrottetii (A. Rich) merr. Extracts, Available online at http; // www.academicjournal.org/JMPR Journal of Medicial Plant Research vol. 3 (7), pp. 5511-518.

Yuniarti Tuty. 2012. Media and Reagensia of Teaching Materials Department of Health Analyst Polytechnic Ministry of Keshatan Kendari. 